JURNAL PATTINGALLOANG

(C)Jurusan Pendidikan Sejarah Fakultas Ilmu Sosial Universitas Negeri Makassar

\title{
Upacara Gaukang Tu Bajeng Kabupaten Gowa 1945-2017
}

\author{
Kusuma Ningrum, Najamuddin, Asmunandar \\ Pendidikan Sejarah FIS UNM \\ kusuma.ningrum0595@gmail.com
}

\begin{abstract}
Abstrak
Penelitian ini bertujuan untuk mengetahui gambaran tentang latar belakang terbentuknya Gaukang dalam masyarakat Sulawesi Selatan, Upacara Gaukang Tu Bajeng pada masa awal kemerdekaan dan masa sekarang, serta Pandangan masyarakat terhadap Upacara Gaukang Tu Bajeng kabupaten Gowa. Penelitian ini bersifat deskriptif historis dengan menggunakan metode penelitian sejarah,melalui tahapan-tahapan kerja yang meliputi; heuristik, kritik, interpretasi, dan historiografi. Heuristik adalah tahap pengumpulan sumber- sumber sejarah, sumber tersebut kemudian dikritik untuk mendapatkan fakta dengan fakta lainnya. Sebagai tahap terakhir adalah historiografi atau penyajian, yaitu merekontruksi peristiwa-peristiwa sejarah menjadi kisah sejarah dalam bentuk deskriptif historis. Hasil penelitian menunjukkan bahwa Gaukang sebagai simbol kekuatan leluhur dipercaya oleh masyarakat sebagai jimat yang dapat menyelamatkan mereka.Gaukang menjadi benda yang sakral dan sangat dihormati.Ketertarikan Tuan Fukusima untuk melihat benda Gaukang di Bajeng/ Limbung membuat masyarakat Limbung mengadakan suatu Upacara yang bernama Upacara Gaukang tu Bajeng.Upacara ini terus diaksanakan setiap tahun untuk mengenang para pahlawan di wilayah Limbung/Bajeng dalam merebut maupun mempertahankan kemerdekaan.
\end{abstract}

\section{Kata Kunci: Upacara Gaukang, Bajeng Kabupaten Gowa}

\begin{abstract}
Abstrac
This study aims to know the background behind the formation of Gaukang in South Sulawesi society, Gaukang Tu Bajeng Ceremony in the early days of independence and now, and the public view of Gaukang Tu Bajeng ceremony of Gowa district. This study is historical descriptive by using historical research methods, through the stages of work that includes; heuristics, criticism, interpretation, and historiography. Heuristics is the stage of collecting historical sources, the source is then criticized for getting the facts with other facts. As the last stage is historiography or presentation, which is reconstructing historical events into historical stories in the form of historical descriptive. The results showed that Gaukang as a symbol of the strength of ancestors believed by the public as a talisman that can save them. Gaukang become a sacred and highly respected object. The interest of Mr. Fukusima to see Gaukang objects in Bajeng / Limbung make Limbung society hold a ceremony called Ceremony Gaukang tu Bajeng. This ceremony is held every year to commemorate the heroes of the Limbung / Bajeng region in seizing and maintaining independence.
\end{abstract}

Keywords: Ceremony Gaukang, In Bajeng Gowa Regency 


\section{A. Pendahuluan}

Upacara tradisional adalah sarana pengokohan nilai-nilai budaya dari suatu kebudayaan masyarakat penduduknya, berfungsi sebagai sarana kegiatan melestarikan norma-norma, serta nilai-nilai budaya yang berlaku dalam masyarakat secara turuntemurun.Norma-norma serta nilai-nilai budaya tersebut, menjadi pegangan masyarakat dalam kehidupan sosialnya agar tetap dipatuhi dan ditaati oleh para pendukungnya (Marhaeni, 2011)

Sulawesi Selatan memiliki ragam etnik yang unik, dengan pelbagai budaya dan adatnya yang masing-masing dianut dan dipercayai oleh masyarakat sekitar, penghargaan terhadap nilai budaya di Sulawesi Selatan masih sangat kental dengan beberapa upacara adatnya, salah satunya adalah upacara adat gaukang di Gowa. Menurut salah satu sumber, yaitu kamus bahasa Makassar, kata gaukang berasal dari bahasa Makassar, yaitu gauk yang kemudian mendapat akhiran ang artinya bekerja (kegiatan) atau pengabdian hamba kepada sesuatu yang sangat dihormati (Arief, 1995).

Penghormatan terhadap kegiatan upacara adat gaukangdalam masyarakat memunculkan semangat kebersamaan dan gotong royong yang sudah berurat dan berakar dalam masyarakat. Dalam kegiatan ini akan menimbulkan adanya pembangunan nasional yaitu mewujudkan suatu masyarakat adil dan makmur yang merata baik secara materil dan spiritual berdasarkan pancasila. Demikian halnya yang terjadi dalam masyarakat Bajeng, Upacara adat yang digelar setiap tahunnya ini menjadi upacara adat yang berbeda dari daerah lainnya.Selain karena dirangkaikan dengan kegiatan pengibaran bendera merah puth juga dalam selang waktu dua tahun sekali diadakan pengiringan benda pusaka kerajaan Bajeng ke Bungung Barania.

Menjelang masa kemerdekaan (1945), ketika Indonesia di jajah oleh Jepang termasuk di wilayah Sulawesi Selatan khususnya wilayah Bajeng (Limbung) kabupaten Gowa. Datang seorang perwira Jepang yang bernama Fukusima.Ia datang dengan cara yang lain dengan sifatnya yang tidak sama pula dengan orang jepang lainnya Kedatangan Fukusima ke Balla Lompoa ingin mengadakan musyawarah dengan pemuka penduduk Bajeng (Limbung) dengan cara mendekati Batang Banoa Appaka (pemuka adat di Balla Lompoa Bajeng).

"Ia datang ki Limbung untuk melihat gaukang yang tersimpan di Balla Lompoa. Semula maksud dari Fakusima itu mendapat tantangan yang keras terutama dari para pemuka-pemuka masyarakat karena menganggap bahwa gaukang itu adalah barang keramat dan tidak bisa dilihat tanpa suatu upacara khusus. Akan tetapi, karena yang datang itu adalah orang Jepang yang berkuasa pada saat itu maka atas dasar pandangan dan anjuran dari beberapa orang termasuk Batang Banoa Appaka yang menjadi penanggung jawab atas pemeliharaan Gaukanga tersebut, akhirnya kotak Gaukang Tu Bajeng di Limbung di buka dan dikeluarkan dua buah benda. Dua buah benda tersebut tidak lain adalah dua lembar bendera berwarna putih dan merah (Arfah Muhammad, 1995).

Hingga pada tanggal 14 agustus 1945 upacara gaukang digelar. Opsir tuan Fukusima menyampaikan pidato di depan rumah adat Balla Lompoa. Sepertinya kedatangan Fukusima dengan cara pendekatannya tersebut mampu menambah semangat para tokoh dan pemuda Bajeng dalam bersiap mempertahankan negerinya dari serangan balik tentara sekutu.

"Saat opsir Jepang Tuan Fukusima berpidato di depan rumah adat Balla lompoa Limbung pada 14 Agustus 1945. Pidato beliau diterjemahkan oleh 
Abd.Salam Dg.Sikki, guru Madrasah Muallimin Limbung. Isi pidato tuan Fukusima bertanya pada pemuda, Apakah Saudara rela dijajah kembali?secara spontan warga menyatakan 'tidak!'. Jepang kemudian menyerahkan senjatanya dan saat itu pula telah dibentuk organisasi kelaskaran di Bajeng sebagai cabang dari Lipang Bajeng di Polongbangkeng" (Syarifuddin, 2007).

Upacara Gaukang $\mathrm{Tu}$ Bajeng sendiri dikenal sebagai pesta besar orang Bajeng yang dilaksanakan di halaman rumah adat Balla Lompoa, pada puncak acaranya warga Bajeng yang mengenakan pakaian adat Sulawesi Selatan itu mengibarkan bendera pusaka yang disebut dengan Bendera jole-jole. Sebuah bendera berwarna merah dengan ornamen warna putih kegiatan ini dilaksanakan setiap tahunnya sebelum upacara 17 Agustus untuk mengenang perlawanan rakyat setempat.

Upacara adat yang dikenal dengan "Gaukang Tu Bajeng" ini digelar setiap tahunnya pada tanggal 14 Agustus. Tanggal 14 Agustus tersebut dipilih untuk mengenang perlawanan rakyat setempat 72 tahun silam. Pasalnya, pada hari Selasa, 14 Agustus 1945 rakyat setempat telah mengibarkan bendera merah putih lebih awal mengawali proklamasi kemerdekaan yang jatuh tiga hari setelahnya. Gaukang Tu Bajeng ini adalah pesta adat masyarakat di sini untuk mengenang peristiwa jelang kemerdekaan dan hal ini menegaskan bahwa bendera merah putih lebih dahulu berkibar di angkasa Bajeng yakni tanggal 14 Agustus 1945," kata Makmur Daeng Sitakka, ketua adat kerajaan Bajeng (Kompas, 2016).

Mengingat keberadaan dan peran upacara adat gaukang begitu penting, maka penulis merasa tertarik untuk mengkaji secara mendalam mengenai Upacara Gaukang tu Bajeng dalam perspektif sejarah budaya. Alasan lain yang tidak kalah penting sehingga mendorong penulis untuk mengkaji lebih jauh tentang Upacara Gaukang ini didasarkan pertimbangan, bahwa beberapa sumber yang mengungkap tentang gaukanga sangat terbatas. Beberapa diantaranya kajian sejarah dan budayanya sangat kurang dan tidak menunjukkan sebagai karya ilmiah sekaligus karya tersebut ditulis oleh bukan yang berlatar belakang sejarah. Karya yang dimaksud adalah buku tentang "Profil Sejarah Budaya dan Pariwisata Gowa yag ditulis oleh Syahrul Yasin Limpo dan kawan - kawan. Yang hanya menjelaskan tentang keberaadaan bendabenda pusaka peninggalan kerajaan Bajeng di Balla Lompoa.

\section{B. Metode Penelitian}

Adapun tahap yang dilakukan dalam penelitian ini adalah sebagai berikut. Heuristik: Merupakan pengumpulan data atau sumber yang merupakan tahapan pertama pada pensusunan skripsi ini.Langkah awal dalam kegiatan ini adalah mencari sumber-sumber berhubungan dengan pembahasan secara keseluruhan dalam tulisan ini, baik sumber primer maupun skunder.Sumber-sumber primer yang digunakan penulis adalah beberapa dokumentasi berupa foto mengenai kegiatan upacara Gaukang tu Bajeng dari tahun 2013 sampai tahun 2016. Dan ada dua cara untuk melakukan peneitian dalam hal pengumpulan data yaitu pertamadengan pengumpulan secara langsung dan pengumpulan sumber pustaka.

Pengumpulan Sumber pustaka dilakukan melalui buku hasil penelitian dan skripsi di perpustakan Universitas Negeri Makassar, Perpustakaan jurusan Sejarah, dan koleksi perorangan dan sebagian besar diperoleh dengan menfoto copy dan meminjam buku. Kritik sumber: setelah memperoleh sumbersumber yang cukup memadai, selanjutnya dilakukan kritik (penyaringan) terhadap sumber tersebut. Kritik terhadap sumber bertujuan untuk memperoleh fakta-fakta yang seobyektif mungkin, sehingga karya sejarah yang dihasilkan merupakan produk dari proses ilmiah yang dapat dipertanggung 
jawabkan, bukan hasil dari suatu fantasi maupun manipulasi (Helius Sjamsuddin, 2012) Interprestasi: Tahapan selanjutnya setelah proses kritik adalah penginterpretasian. Pada tahap interpretasi ini, subyektivitas seorang peneliti akan mulai tampak. Hal ini dapat dipahami karena pada tahap ini imajinasi dibutuhkan untuk menafsirkan seluruh kejadian berdasarkan fakta-fakta sejarah yang telah diperoleh pada tahapan sebelumnya. Terlepas dari hal demikian, peneliti harus bersifat obyektif agar karya yang diperoleh nantinya merupakan karya sejarah yang berkualitas. Historiografi:, yakni menyampaikan sintesa yang diperoleh dalam bentuk kisah sejarah, ini merupakan langkah terakhir menyajikan data dan fakta yang telah dirumuskan dan di analisa ke dalam bentuk penyajian yang utuh dan menarik.Kegiatan ini disebut historiografi (penulisan seejarah).

\section{Hasil dan Pembahasan \\ 1. Latar Belakang Lahirnya Gaukang dalam Masyarakat Sulawesi Selatan}

Meski hampir tidak ada pembahasan mengenai asal-usul gaukeng atau arti penting dari gaukang, akan tetapi kita masih dapat memahaminya melalui contoh serupa di tempat lain di wilayah Asia tenggara. Kepercayaan terhadap dewa-dewa penjaga yang bersemayam di batu-batu dapat ditemukan di Asia Tenggara, india dan China dan salah satu penjelasan terinci tentang hal ini dibuat oleh ilmuwan Prancis, Paul Mus yang menjelaskan tentang batu-batu keramat I Champa kini Vietnam bagian tengah. Champa adalah nama sebuah kerajaan yang penduduknya dari ras bangsa Indonesia yang mengembangkan peradaban mengesankan antara abad ke-9 hingga ke-14. Menurut Mus orang-orang Cham percaya bahwa Dewa Tanah, yang mengandung energi - energi pemberi hidup bagi dunia, bersemayam dalam batu-batu tadi.Batu- batu ini bukanlah representasi, namun Dewa Tanah yang sebenarnya dibuat kasat mata bagi
manusia.Karena Dewa Tanah tidak mampu berkomunikasi dengan manusia dalam bentuk seperti itu, jadi perlu ada perantara bagi manusia dan dewa.Orang yang menjadi perantara diangkat oleh sesama mereka menjadi pemimpin spiritual dan keduniawian bagi komunitasnya karena perannya sebagai juru bicara bagi Dewa Tanah.Batu-batu keramat di Champa ini kelihatannya mempunyai kesamaan asal - usul, makna dan fungsi dengan Gaukang di Sulawesi Selatan (Andaya, 2013)

Menurut tradisi yang hidup didalam masyarakat menyangkut riwayat terbentuknya kesatuan masyarakat bahwa terbentuknya banua-banua (kerajaan kecil), diawali dengan ditemukannya sebuah benda yang terbentuk aneh, biasanya berbentuk atau berwujud ; sepotong kayu, sebuah gambar, sepotong besi, sepotong umbi kering dan yang paling umum adalah sebuah batu(Arfah, 1993).Benda yang ditemukan secara ajaib dan dipandang sebagai benda titisan dewata serta dipercaya memiliki atau mempunyai kekuatan ajaib yang menguasai alam dan manusia.

Benda itu kemudian dikenal dengan sebutan gaukang (bahasa Makassar) atau gaukeng (bahasa Bugis).Gaukang ini oleh masyarakat dipercaya sebagai pelindung jiwa masyarakat.Penemu gaukang tersebut kemudian diangkat sebagai pemimpin masyarakat.Kesatuan masyarakat tersebut disebut sebagai masyarakat gaukang (gaukang community. Sedangkan ahli lain menjelaskan bahwa kelompok tersebut dianggap sebagai kelompok kaum kesatuan anang.

Daerah yang merupakan tempat asli gaukang, yang kemudian ditentukan sebagai batas wilayah sebuah komunitas, tidak mampu lagi mencukupi keperluan kelompok komunitas ini.Bagian batu dari komunitas induk pun diberikan, setiap kelompok mendapat gaukang masing-masing. Komunitas ini dianggap sebagai "anak" oleh komunitas "ibu" yang merupakan komunitas gaukang asli, dan gaukang milik komunitas 
"anak" ini dianggap sebagai “ pembantu " bagi gaukang asli itu(Andaya, 2013).

1. Pesta adat Upacara Gaukang tu Bajeng

Upacara Gaukang dikenal dengan penampilan berbagai macam benda-benda suci yang turut memberikan makna terhadap upacara Gaukang. Upacara Gaukang tu Bajeng dilaksanakan sebagai bentuk penghormatan terhadap benda-benda suci peninggalan kerajaan Bajeng yang dianggap suci dan dihormati. Bentuk penghormatan ini dilakukan agar generasi muda kedepannya, dapat mengetahui, menghormati dan mengingat akan adanya benda- benda suci (Gaukang) di Balla Lompoa.

Upacara Gaukang dilaksanakan di Balla Lompoa Bajeng karena di tempat tersebut benda- benda Gaukang disimpan.Bendabenda tersebut merupakan peninggalan kerajaan Bajeng yang digunakan untuk berperang dan peralatan lainnya.Didirikan pada tahun 1906 oleh Batang Banoa Limbung yang merupakan istana raja pada zaman dahulu(Raodah, 2014)

Keberadaan benda-benda kerajaan ini dianggap sakral dan keramat oleh masyarakat(Raodah, 2014). Yang berhak untuk memegang dan mensucikan bendabenda suci tersebut adalah hanya keturunan dari kerajaan Bajeng yang disebut Paerang yang terdiri dari 10 - 12 orang salah satunya berasal dari Panciro. Masyarakat umum tidak ada yang berani melakukannya karena bendabenda tersebut adalah benda sakral atau keramat(Dg.Muang, 2018).Sebelum Paerang ini mengambil Benda- benda suci yang disimpan dalam sebuah kotak Gaukang, mereka mengambil air wudhu terlebih dahulu. Bukan hanya Paerang akan tetapi semua penyelenggara dalam kegiatan upacara Gaukang ini melakukan hal tersebut untuk menghormati dan menjaga kesucian dari benda-benda Gaukang(Nojeng, 2018).

Selain Paerang dan juga Batang Banoa yang harus hadir dalam kegiatan ini adalah Pasussuru' bendera. Sama halnya dengan Paerang, Passussuru' juga harus keturunan keluarga kerajaan Bajeng yang melakukannya tidak dapat digantikan oleh masyarakat umum. Pasussuru' merupakan orang yang memasukkan bendera kerajaan dan bendera perang yang dimasukkan kedalam sebuah bambu khusus yang bernama bulo banua yang panjangnya sekitar 5 meter, sementara kegiatan memasukkan bendera kerajaan dan bendera perang kedalam bambu disebut Assussuru'. Bendera yang dimasukkan kedalam bambu tidak menggunakan tali (seperti memasukkan bendera pada upacara kemerdekaan) melainkan bendera tersebut terdapat sebuah kain yang berentuk seperti lobang yang berguna untuk memasukkan bendera kerajaan dan bendera perang kedalam bambu.

Benda- benda Gaukang ini setiap 2 tahun sekali akan diarak ke Bungung Barania, menurut kepercayaan masyarakat Bajeng, Bungung Barania merupakan tempat yang sakral, pada masa kerajaan Bajeng yakni masa Karaeng Loe sumur ini digunakan untuk memandikan para prajurit Bajeng, agar mereka lebih berani menghadapi musuh (Dg.Muang, 2018). Tidak semua benda yang tersimpan di Balla Lompoa Limbung akan di keluarkan saat upacara Gaukang tu Bajeng dilaksanakan, adapun benda- benda yang akan dikeluarkan adalah sebagai berikut:

\section{a. Bendera}

Sebuah bendera berwarna merah dengan ornamen putih, menurut pesan orang orang tua bendera itu adalah bendera kerajaan Bajeng bernama Jole-Jolea dan sebuah bendera merah polos segi empat panjang adalah bendera perang, dan bila keduanya dikibarkan bersama, maka berarti bahwa Bajeng dalam keadaan darurat atau perang(seputarselatan, 2017).

\section{b. Poke'}

Poke' kadang juga diasosiasikan dengan linggis karena dua fungsinya yang berbeda sebagai senjata tajam dan juga dimanfaatkan untuk kegiatan lain, walaupun sebenarnya Pokelebih identik dengan tombak. Ada empat jenis poke' yang akan dikeluarkan saat 
upacara Gaukang tu Bajeng dilaksanakan yaitu

\section{1) Poke'Tubarani}

Poke' Tubarani ini terbuat dari besi yang diruncingkan ujungnya. Terdiri dari dua jenis, jenis yang pertama lebih runcing dan lebih panjang di bandingkan jenis yang kedua, masing- masing memiliki penutup (sarung) yang terbuat dari bambu.Di pergunakan sebagai senjata sakti pada masa kerajaan Bajeng.

\section{2) Poke'gallang}

Poke' gallang ini terbuat dari tembaga, di percayai tombak tersebut berbisa. Berfungsi sebagai senjata sakti pada masa kerajaan Bajeng.

\section{3) Poke' Tamannyala}

Poke' Tamannyala terbuat dari tembaga, merupakan tombak yang paling sakti dan paling sakral diantara tombak yang lain, bahkan ketika tombak ini dibersihkan orangorang tidak ada yang berani mendekat kecuali orang yang membersihkan.

\section{4) Poke' Bonrangang}

Berbeda dengan jenis Poke' yang lain, pada Poke' Bonrangang ini ujung tombaknya lebih lebar. Sarungannya (penutup) terbuat dari kayu yang dililit dengan benda kuningan.Berfungsi sebagai senjata sakti pada masa kerajaan Bajeng.

\section{a) Tongkat Komando}

Tongkatnya terbuat dari kayu yang diberi warna hitam, ujung tombak terbuat dari besi yang runcing terdapat pula penutup (sarung) yang melindungi ujug tongkat tersebut yang terbuat dari bambu. Tongkat komando digunakan untuk mengawal panglima perang pada masa kerajaan Bajeng.

\section{b) Kris pusaka tu Bajeng}

Kris ini terbuat dari besi, menurut cerita leluhur pembuatan kris ini dengan tangan yang hanya dipijat-pijat, bahkan bekas tangan dari pembuatan kris tersebut masih terlihat sampai sekarang.Sarungnya terbuat dari kayu mengkilat.

\section{c) Lilitan rambut raja Bajeng}

Lilitan rambut raja Bajeng ini dimasukkan kedalam sebuah kain yang terdiri dari dua warna yakni kain berwarna putih dan kain berwarna coklat. Yang akan diperlihatkan saat upacara Gaukang namun kedua bungkusan kain tersebut hanya diletakkan didalam sebuah peti yang akan dibawa saat upacara Gaukang berlangsung.

d) Tombak pengawal

Sama dengan Poke' namun pada tombak ini pada masa kerajaan bajeng ,jenis senjata tajam yang diperuntukkan khusus untuk mengawal raja, sesorang yang memegang senjata ini tidak boleh jauh dari Raja. Tombak ini terbuat dari Kayu pada ujung Tombak terbuat dari tembaga yang diruncingkan.

e) Gallarang Mata Allo

Dihadiahkan kepada mata allo ketika pindah ke kerajaan bajeng, senjatanya bercabang (pada ujung tombak terdapat dua besi yang runcing) (Dg.Nojeng, 2018)

\section{(1) Tahap Pelaksanaan}

\section{(a) Penurunan Benda Pusaka}

Benda pusaka yang terletak di atas loteng pada bagian Balla Lompoa, benda- benda tersebut tersimpan dalm sebuah peti yang kemudian akan dikeluarkan untuk digunakan dalam Upacara Gaukang, namun benda seperti bendera Jole-Jolea yang aslinya sudah tidak dipergunakan lagi karena sudah usang dan rapuh, yang dipergunakan saat ini adalah hanya duplikatnya saja. Yang menurunkan benda-benda tersebut adalah orang-orang khusus yang disebut paerang yang memang ditunjuk langsung berdasarkan keturunan dari kerajaan Bajeng.

Paerang kemudian menuruni tangga membawa benda - benda Gaukang yang diikuti dengan ganrang, para ketua yayasan, 4 batang banoa turun dari atas rumah kemudian masuk kedalam baruga.

\section{(b) Pengibaran Bendera Jole-Jolea}

Paerang kemudian memberikan Bendera kebesaran tu bajeng yang di sebut jole-jolea kepada Pasussuru' bendera, ke 5 orang ini kemudian membawa bendera tersebut dengan bulo banua, di buka baru dimasukkan 
kedalam bambu, dimana bendera perang yang dimasukkan terlebih dahulu kemudian bendera Jole-Jolea, keduanya dimasukkan kedalam bulo banua. Di ikat kemudian 7-9 orang membawanya kelapangan Balla Lompoa, dimasukkan kedalam sebuah lubang yang berdekatan dengan tiang bendera merah putih , kemudian 7-9 orang ini akan memegang bendera jole-jolea secara bersamasama. Ketika bendera sudah berdiri tegak, salah seorang dari Bontomaero akan membacakan Aru' (Angngaru').Kemudian baru upacara pengibaran bendera merahputih.

\section{(c) Pengiringan Benda Pusaka ke Bungung Barania \\ Pengiringan benda pusaka ke Bungung} Barania tidak dilakukan setiap tahun akan tetapi hanya tiga atau dua tahun sekali, selain karena itu merupakan aturan adat terdahulu hal ini juga menurut kami adalah jika situasinya memungkinkan, maka benda pusaka tersebut akan di bawa ke bungung barania namun jika terhalang oleh kendala apapun maka benda tersebut tidak akan kami bawa ke bunggung barania (dg.ngerang, 2018.).

\section{Upacara Gaukang Pada Masa Awal Kemerdekaan Dan Masa Sekarang}

a. Masa Awal Kemerdekaan

Pada awal Bulan Agustus 1945 di Limbung selain kegiatan latihan militer yang dijalani para pemuda, muncul suatu idea atau gagasan yang dicetuskan dari para pemukapemuka masyarakat Limbung yang dikenal sebagai "tu bajenga". Dalam gagasan tersebut ialah untuk mengobarkan jiwa dan semangat perjuangan tu Bajenga yang masih terpendam dalam jiwa semua putra-putri dalam mempertahankan hak dan disertai dengan keinginan untuk rela berkorban dalam segala hal yang diperlukan, bahkan dengan nyawa sekalipun.

Untuk mewujudkan dasar pemikiran dalam mengobarkan semangat juang para $\mathrm{Tu}$ Bajenga tersebut, maka pada saat itu disepakati untuk membuka perbendaharaan
Tu Bajenga yaitu sebuah Gaukang (Bendabenda kebesaran) dari Tu bajeng. Dalam gaukang tersebut terdapat sebuah bendera perang dikibarkan menandakan bahwa masyarakat akan berada pada situasi yang sangat genting atau situasi dalam siap melakukan peperangan. Bagi masyarakat Bajeng (dulunya distrik limbung) kegiatan upacara gaukang pada masa awal kemerdekaan, bukan hanya perayaan adat semata tetapi memberikan pengaruh yang besar bagi perjuangan rakyat Limbung dalam mempertahankan kemerdekaan.

Dari 37 kepala kampung atau kepala desa tersebut, wilayah Batang Banoa Appaka menjadi daerah paling penting dalam pusat pemerintahan masyarakat Limbung, selain dengan adanya kantor Distrik pada masa kemerdekaan, tempat itu juga menjadi daerah basis perjuangan orang-orang limbung, tepatnya dirumah kebesaran masyarakat Bajeng atau Ballalompoa ri Limbung, ditempat itulah orang-orang limbung sering dikumpulkan untuk membicarakan atau untuk menyusun strategi apa yang akan digunakan dalam menghadapi penjajahan bangsa Belanda.Selain itu karena tempatnya juga yang letaknya masih seperti hutan membuat tepat tersebut menjadi salah satu tempat strategis bagi masyarakat Limbung (Arfah Muhammad, 1995). Di Limbung pada masa menjelang kemerdekaan, datang seorang perwira Jepang yang benama Fakusima.Ia datang dengan cara yang lain dengan sifatnya yang tidak sama pula dengan orang jepang lainnya. (Arfah Muhammad, 1995).

Pada tanggal 14 agustus dengan suatu upacara kebesaran yang baru kali ini dilakukan dengan disaksikan oleh berpuluhpuluh ribu rakyat dari seluruh rakyat Limbung dan sekitarnya yang mengaku dirinya keturunan rakyat Limbung. Untuk pertama kalinya bendera kebesaran rakyat Limbung di lihatnya, yang menurut cerita Sejarah bernama "jole-jolea (Bole-bolea)". Dengan didampingi oleh bendera perang 
yang berwarnah merah berkibar dengan megahnya depan Balla Lompoa di Limbung dimana berarti pula bahwa mulai saat itu semangat rakyat Limbung yang terkenal dan sekian lamanya terpendam da bersembunyi bahkan tinggal menjadi sebutan saja, telah muncul dan bangkit kembali dalam dada dan jiwa sebagai rakyat Limbung utamanya pemuda-pemuda dan sekaligus menandakan bahwa Limbung dengan rakyatnya siap dalam mempertahankan hak dan kebenaran (Arfah Muhammad, 1995)

Peranan Batang Banoa dalam upacara Gaukang, sangatlah penting, Batang Banoa Appaka merupakan wakil rakyat Bajeng atau legislative, sekaligus eksekutif di wilayah kekuasaan Bajeng silam. Batang Banoa Appaka berarti empat daerah perkampungan dalam wilayah kerajaan Bajeng yang mewakili seluruh daerah kekuasaan dalam wilayah kerajaan Bajeng. Ke empat daerah dimaksud masing-masing Batang Banoa Limbung, Pammase, Mata Allo dan Ballo. Seperti halnya yang dilakukan Tuan Fukusima salah seorang pimpinan tentara Jepang, ketika melihat tentara Belanda sudah memasuki daerah pedesaan di kerajaan Gowa maupun Sulawesi Selatan, Tuan Fukusima melakukan pendekatan dengan anggota Batang Banoa Appaka

Jika pada masa awal kemerdekaan upacara Gaukang tu Bajeng dilaksanakan secara sederhana yakni berupa pengeluaran benda pusaka dari kotak Gaukang, yang hanya dihadiri oleh para Batang banoa dan juga masyarakat setempat.Namun pada masa sekarang, kini kegiatan upacara Gaukang tu Bajeng dapat terlaksana lebih meriah. Seperti pada tahun 2013 dan 2016 kegiatan upacara Gaukang tu Bajeng, Para Tamu yang hadir terdiri dari Tokoh- Tokoh adat, dan keluarga besar Kerajaan Bajeng yang memadati Balla Lompoa, di dalam dan di luar Kompleks, diawal dan diakhir acara dihibur dengan Ganrang Pamanca, Ganrang Pakarena, TariTarian Salonreng, Tari 'Gandarang Bulo'.
Bukan hanya dalam perayaan Upacara Gaukang yang berlangsung meriah namun di tahun yang sama yakni pada tahun 2013 dan 2016 pihak keluarga dari kerajaan Bajeng melakukan pemotongan sapi sebagai bentuk tanda syukur terhadap para leluhur dan pejuang terdahulu.

Kegiatan upacara Gaukang tu Bajeng tidak hanya dilaksanakan di wilayah Balla Lompoa semata. Akan tetapi, selang waktu 2 tahun sekali, benda- benda gaukang seperti keris, poke tamannyala dan benda Gaukang lainnya akan di giring ke Bungung Barania.

Hal ini berkaitan dengan sejarah pada masa kerajaan bajeng, dimana saat masyarakat Bajeng ingin berperang, para kesatria Bajeng mandi terlebih dahulu di Bungung Barania agar para kesatria merasa lebih berani. Hal lain yang membedakan antara Upacara Gaukang pada masa awal kemerdekaan dengan masa sekarang adalah kurangnya kesadaran masyarakat dalam menjaga dan merawat benda pusaka yang ada di Balla Lompoa. Warisan budaya bangsa adalah cermin tingginya peradaban bangsa.Dan salah satu ciri bangsa besar dan maju adalah bangsa yang mampu menghargai dan melestarikan warisan budaya nenek moyang mereka. Semakin banyak warisan budaya masa lampau yang bisa digali dan dilestarikan, maka sudah semestinyalah peninggalan budaya tersebut semakin dihargai. Barulah disadari betapa kaya dan melimpah ruahnya warisan budaya nenek moyang kita yang ternyata selama ini terabaikan, terlantar dan tidak dipedulikan. Penyebabnya bisa karena ketidaktahuan, kurangnya kesadaran dan pemahaman akan pentingnya warisan budaya, maupun karena ingin mendapatkan keuntungan pribadi dengan mengoleksi atau memperdagangkannya.

Warisan atau khazanah budaya bangsa merupakan karya cipta, rasa, dan karsa masyarakat di seluruh wilayah tanah air Indonesia yang dihasilkan secara sendirisendiri maupun akibat interaksi dengan budaya lain sepanjang sejarah keberadaanya 
dan terus berkembang sampai saat ini. Warisan budaya itu mencakup sesuatu yang berwujud seperti candi, istana, bangunan, tarian, musik, bahasa, manuskrip (naskah kuno), dan yang tidak berwujud seperti filosofi, nilai, keyakinan, kebiasaan, konvensi, adat-istiadat, etika dan lain sebagainya. Sebagai sebuah negara yang kaya dengan warisan budaya, sudah sepatutnya pemerintah dan seluruh warga negara Indonesia berkomitmen untuk melestarikan warisan yang sangat tinggi nilainya itu agar tidak musnah, hancur, lapuk, dipindahtangankan, ataupun hilang karena dicuri, dirampas baik dengan terang-terangan maupun secara halus. Namun, yang terjadi pada masyarakat justru mengabaikan dan tidak memperdulikan akan pentingnya pemeliharaan dan menghargai benda- benda pusaka.

Pelaksanaan pengiringan benda - benda Gaukang ke bungung Barania terhenti pada tahun 2013, hal ini dikarenakan terkendala oleh dana dan juga hal- hal lain yang memang memberatkan untuk diadakannya pengiringan benda pusaka ke bungung barania, harusnya dalam 2 tahun berselang benda pusaka akan dibawa ke bungung Barania, rencananya akan dilaksanakan pada tahun 2015 namun terhenti lagi, kemudian juga pada tahun 2017 juga terhenti. Selain itu kini dari tahun ke tahun benda-benda pusaka Gaukang sudah semakin berkurang jumlahnya hal ini dikarenakan terlalu banyak yang pernah menangani, mereka yang tertarik untuk mengambil benda -benda Gaukang ini menjadi hak milik tidak segan- segan untuk mengambilnya dan menyimpannya menjadi koleksi pribadi. Sekarang hanya ada $4-6$ benda pusaka yang tersisa saat upacara Gaukang tu Bajeng dilaksanakan (dg.ngerang, 2018.)

Berbeda dengan tahun 2013 dan 2016 perayaan upacara Gaukang tu Bajeng yang berlangsung lebih meriah. Pada tahun 2017 pelaksanaan upacara Gaukang tu Bajeng hanya diselenggerakan secara sederhana, tanpa adanya tari - tarian yang mengiringi dan juga benda - benda pusaka Gaukang tidak lagi di giring ke Bungung Barania. Meskipun demikian, mengingat besarnya perjuangan para pejuang terdahulu pada masa awal kemerdekaan, sebagian masyarakat baik itu yang berada di luar wilayah Bajeng, seperti Maros, Takalar dan wilayah lain, jika merasa sebagai bagian dari keluarga kerajaan Bajeng maka setiap tanggal 14- Agustus, mereka akan datang berkunjung ke Balla Lompoa untuk melaksanakan upacara Gaukang tu Bajeng, meskipun tanpa mengenakan pakaian adat (baju bodo).

\section{b. Pandangan Masyarakat Bajeng Terhadap Upacara Gaukang}

Tanggapan - tanggapan tentang dunia gaib yang berasal dari nenek moyang serta yang tampak pada berbagai upacara, diantaranya seperti upacara turun sawah, yang disebut Palili. Lukuh kerajaan diarak keliling yang upacara- upacara tersebut dipimpin oleh "puang matowa" dan pengkeramatan terhadap benda-benda seperti “ Kalompoang” atau "Gaukang” merupakan benda- benda pusaka kerajaan (ornament) yang dianggap oleh masyarakat memiliki kekuatan supernatural.

Berbagai pandangan masyarakat Bajeng terhadap upacara Gaukang di Balla Lompoa, dimana dalam upacara tersebut mengandung berbagai makna, pengibaran bendera pusaka dan juga pencucian benda-benda kerajaan yang diakhiri dengan membawa benda-benda pusaka tersebut ke bungung barania, dimana sebagian masyarakat Bajeng mempercayai bahwa dengan melaksanakan Upacara Gaukang ini para nenek moyang atau leluhur kita terdahulu akan memberi berkat atau restu terhadap kesuksesan dan keberhasilan dalam melaksanakan kegiatan misalnya saja, dalam pelaksanaan pesta pernikahan. Adapun tanggapan masyarakat Bajeng terhadap upacara Gaukang yang dilaksanakan di Balla Lompoa Limbung yaitu sebagai berikut: 
a. Menurut Syamsul Rijal Kepala seksi trantip dan bagian keluarga besar dari kerajaan Bajeng, yang sekaligus sebagai salah satu pelaksana dari upacara Gaukang beranggapan bahwa Upacara Gaukang memang menjadi agenda tahunan yang digelar di Balla Lompoa Limbung yang dilaksanakan oleh masyarakat Bajeng(Rijal, 2018).

b. Menurut Syahrir Dg. Situru Staf pemerintahan dan kepala lingkungan di Kelurahan Limbung beranggapan bahwa Upacara Gaukang ini dilaksanakan setiap tanggal 14 Agustus , Upacara ini dilaksanakan untuk mengenang jasa-jasa para pahlawan, bahkan Upacara Gaukang ini dianggap sebagai upacara kemerdekaan (Situru, 2018).

c. Menurut Muh. Kasir Dg. Nojeng beranggapan bahwa upacara Gaukang terkait upacara kemerdekaan yaitu untuk memperingati Sejarah perjuangan bangsa, dalam pelaksanaannya dikibarkan 3 Bendera yaitu bendera pusaka, bendera kerajaan dan juga bendera perang. Upacara Gaukang ini dihadiri oleh pemuka masyarakat bahkan pernah juga dihadiri oleh pak Bupati (tanggal, 2018).

\section{Kesimpulan}

Adapun Kesimpulan yang didapatkan dari pembahasan diatas diantaranya: benda yang ditemukan secara ajaib dan dipandang sebagai benda titisan dewata serta dipercaya memiliki atau mempunyai kekuatan ajaib yang menguasai alam dan manusia. Benda tersebut berwujud seperti sepotong kayu, sebuah gambar, sepotong besi, dan yang paling umum adalah berbentuk batu. Benda itu kemudian dikenal dengan sebutan gaukang (bahasa Makassar) atau gaukeng (bahasa Bugis). Gaukang ini oleh masyarakat dipercaya sebagai pelindung jiwa masyarakat.

Upacara Gaukang tu Bajeng pada masa kemerdekaan dilatar belakangi karena ketertarikan Tuan Fukusima terhadap benda - benda kerajaan Bajeng yang tersimpan di
Balla Lompoa, seiring berjalannya waktu upacara Gaukang tu Bajeng pada masa sekarang dimanfaatkan sebagai upacara untuk menghormati dan mengenang para leluhur.

Masyarakat beranggapan bahwa Upacara Gaukang tu Bajeng merupakan upacara yang wajib dihadiri oleh keluarga kerajaan Bajeng dan masyarakat umum lainnya.

\section{DAFTAR PUSTAKA}

Andaya, Y. L., 2013. Warisan arung Pallakka, Sejarah Sulawesi selatan abad ke 17. Makassar: Inninnawa.

Arfah Muhammad, d., $1995 . \quad$ Sejarah Perjuangan Bangsa di Daerah Sulawesi Selatan. Ujung Pandang: Departemen pendidikan dan Kebudayaan.

Arfah, M. d., 1993. Haji Andi Mappanyukki Biografi Pahlawan Haji Andi Mappanyukki, Sultan Ibrahim Profil Nasionalis dan Patriotik Sejati Yang konsekuen terhadap Republi. Ujung Pandang: Departemen Pendidikan dan kebudayaan..

Arief, A., 1995. Kamus Makassar Indonesia. Ujung Pandang: Kapita DDI Ujung Pandang.

Dg.Muang, M., 2018. Upacara Gaukang tu Bajeng [Interview] (12 April 2018).

dg.ngerang, H. m., 2018.. Upacara Gaukang tu Bajeng [Interview] (16 05 2018.).

Dg.Nojeng, M., 2018. Wawancara tentang alat- alat yang digunakan saat Upacara Gaukang tu Bajeng [Interview] (03 mei 2018).

Helius Sjamsuddin, 2012. Metodologi Sejarah. Yogyakarta: Ombak.

Marhaeni, S. d., 2011. Accera Kalompoang: Studi Sejarah di Balla Lompoa di 
Kabupaten Gowa. 1 ed. Makassar: Rijal, S., 2018. wawancara pandangan Universitas Negeri Makassar . masyarakat [Interview] (08 05 2018).

Nojeng, M. d., 2018. Wawancara Upacara Gaukang tu Bajeng [Interview] (12 04 2018).

Syarifuddin, D., 2007. Rakyat Gowa Menentang Penjajah. Makassar: Pustaka Refleksi.

Raodah, 2014. Budaya spiritual orang Gowa. Makassar: pustaka refleks. 